\title{
ANTIBIOTIC-INDUCED COLITIS IMPLICATION OF A TOXIN NEUTRALISED BY CLOSTRIDIUM SORDELL.II ANTITOXIN
}

G. D. RIFKIN

J. Silva, JR.

Division of Infectious Diseases, Department of Internal Medicine, University of Michigan Medical Center, Ann Arbor, Michigan, U.S.A.

\section{R. B. SACK}

Department of Medicine, Baltimore City Hospital and fohns Hopkins University, Baltimore, Maryland

Summary A toxin(s) has been demonstrated in the stools of two patients with antibioticassociated colitis. This toxin(s) was heat-labile, wasrapidly lethal for hamsters, increased vascular permeability in rabbit skin, and was cytotoxic for cells in tissue-culture. It was neutralised by Clostridium sordellii antitoxin but not by antitoxins prepared against otherclostridia; $E s c h e r-$ ichia coli, and Vibrio cholerce toxins. These characteristics were identical to those of a toxin implicated in the ætiology of antibiotic-induced colitis in the hamster. One patient improved rapidly after treatment with oral vancomycin, and at the same time the toxin disappeared from the stool.

\section{Introduction}

Pseudomembranous colitis has been recognised as a complication of antimicrobial therapy since $1952 .^{1} \mathrm{In}$ recent years, clindamycin, lincomycin, and ampicillin have been most frequently associated with this disease. ${ }^{2,3}$ While the pathogenesis has remained unclear, Larson et al. have implicated a heat-labile toxin found in the fæces of patients with pseudomembranous colitis. ${ }^{4}$ We have demonstrated a similar toxin and its neutralisation by polyvalent clostridial antitoxin in hamsters with clindamycin-induced ileocæcitis. ${ }^{5}$ This study shows the presence of toxin(s) in fæces of two patients with antibiotic-associated colitis and the neutralisation of the toxin's activities by in-vitro incubation with Clostridium sordellii antitoxin. Resolution of the illness and disappearance of the toxin followed oral vancomycin in one patient.

\section{Patients and Methods}

Case I.-A $1 \frac{1}{2}$-year-old boy with an imperforate anus underwent closure of his colostomy. He received 1 day of preopertive and 4 days of postoperative clindamycin (total dose 2250 $\mathrm{mg}$ ) and gentamicin (total dose $150 \mathrm{mg}$ ). 1 day after these antibiotics were discontinued, he had tarry stools and diarrhoea. Stool cultures contained no enteric pathogens. During the next 3 weeks he had intermittent fever and respiratory distress. A barium enema suggested pseudomembranous colitis. On the 27 th postoperative day he received one dose of ampicillin ( 320 $\mathrm{mg}$ intravenously), and then chloramphenicol $(160 \mathrm{mg}$ intramuscularly every 6 hours) and gentamicin (16 mg intravenously every 6 hours). His condition' deteriorated and 24 hours later a laparotomy revealed a diffusely dilated, œdematous colon with a grey pseudomembrane. A sigmoid colostomy was re-established and a stool sample was obtained for toxicity studies. He died postoperatively from hypotension and ventricular tachycardia. Pseudomembranous colitis limited to the colon was confirmed at necropsy.

Case II.-A 13-year-old girl was transferred from another hospital on lieb. 5, 1977, with fulminant $\mathrm{HB}_{\mathrm{s}} \mathrm{Ag}$-negative hepatitis. Stage-Iv encephalopathy developed despite treatment with corticosteroids, oral neomycin, fluids, and nutritional support. Two exchange transfusions were carried out within 72 hours of admission and within 30 hours she became conscious and had no abnormal neurological signs. 3 weeks later, an 8-day course of ampicillin was given (total dose $70 \mathrm{~g}$ ) for a urinary-tract infection. Intermittent abdominal pain, vomiting, and fever developed during treatment. On March 23, 1977, the urinary-tract infection recurred, and she was treated again with ampicillin $(10 \mathrm{~g} /$ day $)$ and gentamicin $(240 \mathrm{mg} /$ day $)$ for 14 days. Urinary symptoms and pyuria cleared up, but her temperature rose to $39.4^{\circ} \mathrm{C}$, the abdominal pain increased, and diarrhcea developed. Sigmoidoscopy with biopsy on April 13, 1977, revealed pseudomembranous colitis. Treatment with oral vancomycin ( $500 \mathrm{mg}$ every six hours) was started, and within 24 hours her diarrhœea ceased. Within 2 days she was afebrile and without abdominal pain. Vancomycin was continued for 10 days without complications. Stools were obtained for study shortly before and again on the 2 nd and 4 th days of therapy with vancomycin.

Preparation of stool filtrates.-Fæcal samples from the two patients were diluted $1: 1(\mathrm{v} / \mathrm{v})$ with $0.85 \% \mathrm{NaCl}$ (saline) and centrifuged at $10000 \mathrm{~g}$ for 30 minutes at $4^{\circ} \mathrm{C}$. The supernatants were then sterilised by filtration through $0.22 \mu \mathrm{m}$ millipore membranes and the filtrates stored at $-70^{\circ} \mathrm{C}$. Control filtrates were prepared from stool samples of patients with active ulcerative colitis (4 patients), active granulomatous colitis (3), acute salmonella enteritis (1), non-specific enteritis (3), and normal children (2). Toxicity tests were carried out with filtrates before and after they had been neutralised or physicochemically altered, and with control solutions.

Neutralisation of filtrates.-Filtrates from the two patients were incubated at room temperature $\left(21^{\circ} \mathrm{C}\right)$ for 30 minutes with gas-gangrene polyvalent antitoxin (P.C.A.) (Lederle, Pearl River, N.J., control no. 339-244); the individual U.S. standard clostridial antitoxins contained in P.C.A. (Cl. perfringens, $\mathrm{Cl}$. septicum, $\mathrm{Cl}$. histolyticus, $\mathrm{Cl}$. odematiens, and Cl. sordellii) (Dr E. Seligmann, F.D.A., Bureau of Biologics, Rockville, Md.); Cl. perfringens, $C l$. novyi $A$ and $B$, and $\mathrm{Cl}$. septicum antitoxins (Burroughs Wellcome Co., Research Triangle Park, N.C.); human immune serum globulin (H.I.s.g.) (Merck, Sharp and Dohme, West Point, Pa., control no. 1170); or mycoplasma-free horse serum (Difco, Detroit, Mi).

As filtrate from case I was also tested for Esch. coli enterotoxin-like activity, neutralisation of his filtrate was attempted in Y-1 adrenal cells with heat-labile Esch. coli enterotoxic antisera $^{6}$ and Swiss Serum Vaccine Institute cholera antiserum (N.I.H., Bethesda, Md.) by the method of Sack. ${ }^{7}$

Physicochemical treatment of filtrates.-Filtrates were heated at $56^{\circ} \mathrm{C}$ for 30 minutes, incubated with trypsin (100 $\mu \mathrm{g} / \mathrm{ml}$ ) or pronase $(100 \mu \mathrm{g} / \mathrm{ml})$ (Sigma Chemical Company, St. Louis, Mo.) at $37^{\circ} \mathrm{C}$ for 24 hours, or had their $\mathrm{pH}$ adjusted with $1 \mathrm{~mol} / 1 \mathrm{HCl}$, or $1 \mathrm{~mol} / 1 \mathrm{NaOH}$.

Control solutions.-These consisted of solutions of P.C.A., H.I.S.G., $\mathrm{Cl}$. sordellii antitoxin, other clostridial antitoxins, pronase, trypsin, and saline.

Toxicity studies in hamsters.-Male golden (Syrian) hamsters (Charles River Breeding Laboratories, Newfield, $\mathrm{N} . \mathrm{J}$.) weighing 60-90 $\mathrm{g}$ were injected intraperitoneally with $10-200 \mu \mathrm{l}$ of the filtrates or control solutions. Hamsters were weighed daily, if they became moribund they were killed, and submitted to necropsy, otherwise necropsies were carried out within $24 \mathrm{~h}$ of death. Tissues were sent for histological examination.

Assay of vascular permeability factor in rabbit skin. - New Zealand white rabbits (Langshaw, Augusta, Mi.) 
were depilated and injected intradermally with $100 \mu$ l of filtrate or control solutions. Evans blue dye (2\%) was injected intravenously 24 hours later; diameters of areas of odema, of hæmorrhage, and of increased permeability (seen as "bluing" due to dye leakage) were measured after 2 hours according to the method of Evans et al. ${ }^{8}$ Each solution was tested in at least two rabbits and the mean diameter of the lesions was recorded. Solutions giving a mean diameter of bluing of at least $5 \mathrm{~mm}$ were considered positive for permeability factor.

Assay of cytotoxicity in tissue cultures.-Confluent monolayers of WI-38 human diploid fibroblasts and hela cells (HEM Research Inc., Rockville, Md.), were inoculated with 100 $\mu$ of filtrate preparations or control solutions and examined microscopically at 24 and 48 hours. Reactions were graded visually as: negative $=$ no change in cells; weakly positive $=$ $50-75 \%$ cells rounded; positive $=75-100 \%$ cells rounded and monolayer disrupted.

Stool filtrate from case I was tested for Esch. coli heat-labile enterotoxin-like activity in Y-1 adrenal cells by the method of Sack and Sack. ${ }^{9}$

\section{Results}

Toxicity for hamsters. - All hamsters injected intraperitoneally with $100 \mu$ l of filtrate from case I died within 24 hours (table 1). Weight loss, diarrhœa, hæmaturia, and death within 4 to 10 days occurred in $40 \%$ of animals receiving $10 \mu$ of filtrate from case 1 . Necropsies on hamsters receiving 10 or $100 \mu$ of filtrate revealed hæmorrhages in the cæcum and omental and mesenteric fat, ileal and cæcal distension, and pleural effusions; blood clots were found in the bladders of those receiving
$10 \mu$ l of filtrate. Microscopic examination confirmed purulent and hæmorrhagic inflammation of the cæcum and serosa.

When $100 \mu$ l of filtrate from case I was incubated with $100 \mu$ l of P.C.A. or H.I.S.G. before injection, the rapidly lethal response was no longer demonstrable (table I). Instead, a toxic syndrome similar to that induced by $10 \mu \mathrm{l}$ of untreated filtrate was noted. These observations sug gested partial neutralisation of filtrate toxicity. Hamsters injected with $100 \mu$ l of P.C.A. or H.I.S.G. remained well

Filtrate prepared from the stool of case II (before vancomycin therapy) was also lethal for hamsters. Intraperitoneal injection of six animals with $200 \mu$ l of filtrate from case II killed half the hamsters within 48 hours. Because only a limited quantity of filtrates from both cases was available, further toxicity tests in hamsters could not be carried out.

Stool specimens obtained from case II 2 and 4 days after starting vancomycin were not toxic for hamsters (each specimen was tested in ten hamsters). Groups of ten hamsters injected with control filtrates or solutions of P.C.A. or H.I.S.G. in saline remained well.

Vascular permeability factor assay in rabbit skin.When rabbits were injected intradermally with stool filtrate from either patient, localised induration and cedema developed within 4 hours and reached their maximum size by 18-24 hours. Vascular permeability factor was produced by filtrates from both patients (table II). Volumes of filtrate $(10 \mu$ l of filtrate from case $I$ and 100 $\mu$ l of filtrate from case 11 ) that induced areas of cdema

TABLE I-EFFECT OF ANTISERA ON MORTALITY OF HAMSTERS GIVEN CASE-I FILTRATE * INTRAPERITONEALLY

\begin{tabular}{|c|c|c|c|c|c|c|c|}
\hline \multirow{4}{*}{$\begin{array}{l}\text { Solution incubated } \dagger \\
\text { with case-I filtrate (amount) }\end{array}$} & \multicolumn{7}{|c|}{ Cumulative mortetity } \\
\hline & \multicolumn{6}{|c|}{ Case-I filtrate } & \multirow{3}{*}{$\begin{array}{c}\begin{array}{c}\text { Normal } \\
\text { saline } \\
\text { (control) } \\
100 \mu l\end{array} \\
\text { Day } 14\end{array}$} \\
\hline & \multicolumn{2}{|c|}{$10 \mu l$} & \multicolumn{3}{|c|}{$100 \mu l$} & $\begin{array}{l}100 u l \text { heated at } \\
56^{\circ} \mathrm{C} \text { for } 30 \mathrm{~min} .\end{array}$ & \\
\hline & Day 7 & Day 14 & Day 1 & Day 7 & Day 14 & Day 14 & \\
\hline $\begin{array}{l}\text { Normal saline }(100 \mu \mathrm{l}) \\
\text { Polyvalent clostridial antitoxin }(100 \mu \mathrm{l}) \\
\text { Human immune serum globulin }(100 \mu \mathrm{l})\end{array}$ & $\begin{array}{l}2 / 10 \\
0 / 10 \\
0 / 10\end{array}$ & $\begin{array}{l}4 / 10 \\
0 / 10 \\
0 / 10\end{array}$ & $\begin{array}{r}10 / 10 \\
0 / 10 \\
0 / 10\end{array}$ & $\begin{array}{l}-\overline{7} \\
7 / 10 \\
5 / 10\end{array}$ & $\begin{array}{l}7 / 10 \\
7 / 10\end{array}$ & $\begin{array}{l}0 / 10 \\
0 / 10 \\
0 / 10\end{array}$ & $\begin{array}{l}0 / 10 \\
0 / 10 \\
0 / 10\end{array}$ \\
\hline
\end{tabular}

*Filtrate derived from the fæces of case $I$.

†Filtrate incubated with saline or antisera at $21^{\circ} \mathrm{C}$ for $30 \mathrm{~min}$ before intraperitoneal injection.

TABLE II-NEUTRALISATION OF FILTRATE TOXICITY BY ANTISERA AS ASSAYED IN RABBIT SKIN AND TISSUE CULTURES

\begin{tabular}{|c|c|c|c|c|c|c|}
\hline \multirow[b]{3}{*}{ Assay } & \multirow[b]{3}{*}{$\begin{array}{c}\text { Filtrate } \\
\text { source } \\
(10 \mu l \text { per test })\end{array}$} & \multicolumn{5}{|c|}{ Solution preincubated with filtrate } \\
\hline & & \multirow[b]{2}{*}{$\begin{array}{l}\text { Saline } \\
(90 \mu 1)\end{array}$} & \multicolumn{4}{|c|}{ Antisera } \\
\hline & & & $\begin{array}{l}\text { Polyvalent } \\
\text { clostridia } \\
\text { antitoxin } \\
(10 \mu \mathrm{l})\end{array}$ & $\begin{array}{c}\text { Human } \\
\text { immune serum } \\
\text { globulin } \\
(10 \mu l)\end{array}$ & $\begin{array}{l}\text { Cl. sordellii } \\
\text { antitoxin } \\
\text { (1 unit) } \ddagger\end{array}$ & $\begin{array}{l}\text { Horse serum } \\
\qquad(90 \mu l)\end{array}$ \\
\hline $\begin{array}{l}\text { Rabbit } \\
\text { skin * }\end{array}$ & $\begin{array}{l}\text { Case I. } \\
\text { Case II. }\end{array}$ & $\begin{array}{l}\text { Pos. } \\
\text { Pos. }\end{array}$ & $\begin{array}{l}\text { Neg. } \\
\text { Neg. }\end{array}$ & $\begin{array}{l}\text { Neg. } \\
\text { Neg. }\end{array}$ & $\begin{array}{l}\text { Neg. } \\
\text { Neg. }\end{array}$ & $\begin{array}{l}\text { Pos. } \\
\text { Pos. }\end{array}$ \\
\hline $\begin{array}{l}\text { WI- } 38 \dagger \text { and } \\
\text { hela cells }\end{array}$ & $\begin{array}{l}\text { Case I. } \\
\text { Case II. }\end{array}$ & $\begin{array}{l}\text { Pos. } \\
\text { Pos. }\end{array}$ & $\begin{array}{l}\text { Neg. } \\
\text { Neg. }\end{array}$ & $\begin{array}{l}\text { Neg. } \\
\text { Pos. } \$\end{array}$ & $\begin{array}{l}\text { Neg. } \\
\text { Neg. }\end{array}$ & $\begin{array}{l}\text { Pos. } \\
\text { Pos. }\end{array}$ \\
\hline
\end{tabular}

${ }^{\star}$ Pos. $=\geqslant 5 \mathrm{~mm}$ average diameter bluing; $\mathrm{Neg} .=0 \mathrm{~mm}$ diameter of bluing.

$\dagger$ Pos. $=100 \%$ of cells rounded and monolayer disrupted; $\mathrm{Neg} .=$ normal monolayer.

$\ddagger 1$ unit will neutralise $9.3 \mathrm{mg}$ of U.S. standard $\mathrm{Cl}$. sordellii toxin.

$\$$ Negative when incubated with $40 \mu l$ human immune serum globulin. 
TABLE III-PHYSICOCHEMICAL PROPERTIES OF STOOL FILTRATES AS ASSAYED IN RABBIT SKIN AND TISSUE CULTURES

\begin{tabular}{|c|c|c|c|c|c|c|c|c|c|}
\hline \multirow[b]{3}{*}{ Assay } & \multirow{3}{*}{$\begin{array}{c}\text { Filtrate } \\
\text { source } \\
(10 \mu l \text { per test })\end{array}$} & \multicolumn{8}{|c|}{ Physicochemical treatment of filtrates } \\
\hline & & \multirow[b]{2}{*}{ Untreated } & \multirow{2}{*}{$\begin{array}{l}\text { Heated at } \\
56^{\circ} \mathrm{C} \text { for } \\
30 \text { mins }\end{array}$} & \multicolumn{2}{|c|}{ Proteolytic enzymes } & \multicolumn{4}{|c|}{ Effect of pH } \\
\hline & & & & Trypsin & Pronase & pH 4 & $\mathrm{pH} 5$ & pH 9 & pH 10 \\
\hline $\begin{array}{l}\text { Rabbit } \\
\text { skin }^{\star}\end{array}$ & $\begin{array}{l}\text { Case I. } \\
\text { Case II. }\end{array}$ & $\begin{array}{l}\text { Pos. } \\
\text { Pos. }\end{array}$ & $\begin{array}{l}\text { Neg. } \\
\text { Neg. }\end{array}$ & $\begin{array}{l}\text { Pos. } \\
\text { Pos. }\end{array}$ & $\begin{array}{l}\text { Pos. } \\
\text { Pos. }\end{array}$ & $\begin{array}{l}\text { Neg. } \\
\text { Neg. }\end{array}$ & $\begin{array}{l}\text { Neg. } \\
\text { Neg. }\end{array}$ & $\begin{array}{l}\text { Pos. } \\
\text { Pos. }\end{array}$ & $\begin{array}{l}\text { Neg. } \\
\text { Neg. }\end{array}$ \\
\hline $\begin{array}{l}\text { WI-38† } \\
\text { and } \\
\text { hela cells }\end{array}$ & $\begin{array}{l}\text { Case I. } \\
\text { Case II. }\end{array}$ & $\begin{array}{l}\text { Pos. } \\
\text { Pos. }\end{array}$ & $\begin{array}{l}\text { Neg. } \\
\text { Neg. }\end{array}$ & $\begin{array}{l}\text { Pos. } \\
\text { Pos. }\end{array}$ & $\begin{array}{c}\text { Weak pos. } \\
\text { Pos. }\end{array}$ & $\begin{array}{l}\text { Neg. } \\
\text { Neg. }\end{array}$ & $\begin{array}{c}\text { Weak pos. } \\
\text { Pos. }\end{array}$ & $\begin{array}{l}\text { Pos. } \\
\text { Pos. }\end{array}$ & $\begin{array}{l}\text { Neg. } \\
\text { Neg. }\end{array}$ \\
\hline
\end{tabular}

$\star$ Pos $=\geqslant 5 \mathrm{~mm}$ average diameter of bluing; $\mathrm{Neg} .=0 \mathrm{~mm}$ diameter of bluing.

$\dagger$ Pos $=100 \%$ rounded and monolayer disrupted; Weakly Pos. $=50-75 \%$ rounded; Neg. $=$ normal monolayer.

with average diameters of at least $15 \mathrm{~mm}$ also produced intradermal hæmorrhage and areas of increased permeability with mean diameters of at least $8 \mathrm{~mm}$. These effects were neutralised (zero $\mathrm{mm}$ bluing) by incubation of the filtrates with P.C.A., H.I.S.G., and Cl. sordellii antitoxin. Intradermal reactions produced by the filtrates were not altered by incubation with normal horse serum or antisera produced against toxins of $\mathrm{Cl}$. perfringens, Cl. septicum, Cl.cedematiens, and Cl. histolyticus.

Vascular permeability factor(s) present in these filtrates was destroyed by heat, alkalinisation to $\mathrm{pH} 10$ and acidification to $\mathrm{pH} 5$ (table III). Bluing was present at $\mathrm{pH}$ 6. Trypsinisation did not affect the permeability factor but incubation with pronase decreased the extent of odema produced by both filtrates and the capillary permeability produced by $10 \mu$ of filtrate from case I ( 5 mm bluing).

Filtrates prepared from the stool of case il while she was receiving vancomycin therapy did not contain permeability factor. Control filtrates, clostridial antitoxins, and solutions of trypsin, pronase and saline were also inactive.

Tissue culture assay.-The toxicity of filtrates from the two patients for WI-38 human diploid fibroblasts and hela cells corresponded to activity noted in the rabbit skin assay (tables II and III). Cl. sordellii antitoxin was the only clostridial antitoxin that neutralised the toxicity produced by the two patients' filtrates. In this assay, filtrate from case II was more toxic; as little as 1 $\mu$ produced cytotoxicity and a greater quantity of H.I.S.G. was required to neutralise its effect. Both filtrates were active at $\mathrm{pH} 5$ although the cytotoxicity of filtrate from case I was reduced at this $\mathrm{pH}$. Treatment of filtrate from case $\mathrm{I}$ with pronase reduced, but did not abolish, its toxicity.

As with the hamster and rabbit skin assays, filtrates prepared from case II 2 and 4 days after starting vancomycin were not toxic for cell-cultures. Control filtrates, antitoxin solutions, pronase and trypsin were also without effect. Cytotoxicity could not be passed serially.

At a dilution of $1: 1600$, filtrate from case I produced morphological changes in Y-1 adrenal cells similar to those seen with $E s c h$. coli heat-labile enterotoxin. Toxicity was again neutralised by heating and by incubation with P.C.A., but antisera to Esch. coli heat-labile enterotoxin (1:2 dilution) and to $V$. cholera (1:10 dilution) did not neutralise a 1:100 dilution of filtrate from case $I$.

\section{Discussion}

This investigation confirms and extends the findings of Larson et al. that a heat-labile toxin(s) is present in the fæces of patients with pseudomembranous colitis induced by clindamycin and ampicillin. ${ }^{4}$ Our results suggest that the toxin(s) is derived from $\mathrm{Cl}$. sordellii. We found that this factor(s) was rapidly lethal for hamsters, produced odema, hæmorrhage and increased vascular permeability in rabbit skin, and was cytotoxic for WI-38 and hela cells. Toxic properties were neutralised by in-vitro incubation of the stool filtrates with $\mathrm{Cl}$. sordellii antitoxin but not with other clostridial, Esch. coli or $V$. cholerce antitoxins. The lethal effect of our toxin on hamsters, its effect on vascular permeability in rabbit skin, its heat lability, and the $\mathrm{pH}$ at which it is effective, all resemble the properties of $\mathrm{Cl}$. sordellii toxins which cause either adema or hæmorrhage. ${ }^{10}$ Differences in reactivity noted with the three tests we used might be due to different amounts of one or more $\mathrm{Cl}$. sordellii toxins in the two filtrates. In addition, $\mathrm{Cl}$. sordellii toxin obtained from the F.D.A., when tested in hamsters, rabbit skin, and WI-38 and hela cells produced effects identical to those of filtrates from cases I and II (unpublished observations).

Cl. sordellii, although pathogenic for man, has not previously been associated with gastrointestinal disease. Cohn, however, has demonstrated $\mathrm{Cl}$. sordellii toxin production in dogs with bowel obstruction, ${ }^{11}$ a recognised cause of colitis. ${ }^{2}$ His observation and our findings may point to a common pathogenic mechanism responsible for the varied illnesses associated with pseudomembranous colitis in man and animals.

We have demonstrated that clindamycin-induced colitis can be prevented in hamsters by oral vancomycin. ${ }^{12}$ Furthermore, stool filtrate from hamsters protected by vancomycin is not toxic by our assays (unpublished observation). Case II was treated with vancomycin after the onset of colitis and improved within 24 hours. At the same time toxin disappeared from stool filtrates. Vancomycin has been reported to be effective in staphylococcal enterocolitis and pseudomembranous colitis. ${ }^{13} \mathrm{~A}$ recent review has questioned an ætiological role for Staphylococcus aureus in pseudomembranous colitis; ${ }^{2}$ we did not isolate staphylococci from stools of cases I and II, nor from hamsters with colitis. We do not believe staphylococci are pathogenically important. Moreover, the response to vancomycin therapy reported previously, in hamsters, and now in one of our patients, warrants a controlled clinical trial of this drug for the treatment of antibiotic-induced colitis.

We hope this brief report will suimulate microbiological and toxicological studies of all cases of pseudomem- 
branous colitis in order to define more clearly the role of $\mathrm{Cl}$. sordellii, and possibly that of other toxin-producing organisms, in this disease.

This study was supported by the Frederick Novy Infectious Diseases Research Fund and by the Upjohn Company, Kalamazoo, Michigan.

Requests for reprints should be addressed to: G. D. R., Division of Infectious Diseases, University Hospital, Ann Arbor, Michigan 48109 , U.S.A.

\section{REFERENCES}

1. Reiner, L., Schlesinger, M. J., Miller, G. M. Archs Path. 1952, 54, 39.

2. Bartlett, J. G., Gorbach, S. L. Adv. intern. Med. 1977, 22, 455.

3. Lusk, R. H., Fekety, F. R., Silva, J., Bodendorfer, T., Devine, B. J., Kawanishi, H., Korff, L., Nakauchi, D., Rogers, S., Siskin, S. B. f. infect. Dis. 1977, 135, Suppl., S111.

4. Larson, H. E., Parry, J. V., Price, A. B., Davies, D. R., Dolby, J., Tyrrell, D. A. J. Br.med. F. $1977, \mathrm{i}, 1246$.

5. Rifkin, G. D., Silva, J., Fekety, R. Gastroenterology. (in the press).

6. Sack, R. B. Infect. Immun., 1975, 12, 1475 .

7. Sack, R. B. ibid. 1973, 8, 641

8. Evans, D. G Evans, D. J Gorbach, S. L ibid 1973, 8, 725

9. Sack, D. A., Sack, R. B. ibid. 1975, 11, 334

10. Arseculeratine, S. N., Panabokké, R. G., Wijesundera, S. f. med. Microbiol. $1969,2,37$.

11. Bornside, C. H., Floyd, C. E., Cohn, I. J. surg. Res. 1964, 5, 233.

12. Browne, R A Fekety, R, Silva, J, Boyd, D. I., Work, C. O., Abrams, G. D. Johns Hopkins med. Y. 1977, 141, 183

13. Kahn, M. Y., Hall, W. H. Ann. intern. Med 1966, 65, 1

\section{CLOFIBRATE INCREASES LIPOPROTEIN-LIPASE ACTIVITY IN ADIPOSE TISSUE OF HYPERTRIGLYCERIDEMIC PATIENTS}

K. G. TAYLOR

G. HOLDSWORTH

D. J. Galton

Diabetes and Lipid Laboratory, St. Bartholomew's Hospital, London

Summary Clearance of plasma-triglycerides and activity of lipoprotein lipase in adipose tissue were studied in six hypertriglyceridæmic patients before and after a week of clofibrate therapy ( $2 \mathrm{~g} /$ day $)$. Plasma-triglycerides decreased significantly from $6.85 \pm 1.1$ to $2.66 \pm 0.29 \mathrm{mmol} / \mathrm{h}$ and triglyceride clearance increased significantly from $1.3 \pm 0.2$ to $2.4 \pm 0.4 \% / \mathrm{min}$. There were concomitant significant increases in heparin-releasable lipoprotein lipase $(95 \pm 16$ to $181 \pm 34 \mathrm{nmol}$ free fatty acids $/ 10^{6}$ cells $/ \mathrm{h}$ ) and in extractable lipase $(88 \pm 14$ to $179 \pm 28 \mathrm{nmol}$ free fatty acids $/ 10^{6}$ cells $/ \mathrm{h}$ ). It is concluded that an important effect of clofibrate may be to increase the levels of adipose-tissue lipoprotein lipase and thereby improve the clearance of plasma-triglycerides.

\section{Introduction}

Clofibrate is extensively used in the treatment of hypertriglyceridæmias. However, its mechanism of action is not clearly understood. The possibility that clofibrate may improve the clearance of very-low-density lipoprotein (V.L.D.L.) was suggested by the demonstration of increased levels of post-heparin plasma-lipoprotein-lipase activity after treatment with this drug. ${ }^{1-3}$ Plasma-lipoprotein-lipase catalyses the rate-determining step for the removal of triglycerides from the blood.

An increase in levels of lipoprotein lipase in adipose tissue during ciofibrate therapy has previously been observed in the rat, ${ }^{4}$ but not in man. We have studied the effect of clofibrate therapy on lipoprotein-lipase activity in adipose tissue, and plasma-triglyceride clearance in six hypertriglyceridæmic patients.

\section{Patients and Methods}

Six male patients (mean age $51 \pm 2$ years, mean weight $76.2 \pm 3.3 \mathrm{~kg}, 14+6 \%$ above ideal weight, mean fasting bloodglucose $5.4 \pm 0.8 \mathrm{mmol} / 1$, mean fasting plasma-triglyceride $6.85 \pm 1.1 \mathrm{mmol} / \mathrm{l}$ ) were investigated. Before admission to the study plasma-triglyceride was determined on at least two occasions while the men were fasting. Secondary causes of hypertriglyceridæmia such as excess alcohol intake and renal disease were excluded. Three patients were slightly glucose intolerant. All were classified as having W.H.O. type IV lipoproteinæmia by electrophoresis. Informed consent was obtained before hospital admission. None of the patients was receiving drug therapy, and they were all on unrestricted diets before and during the period in hospital. The mean weight of the group decreased to $73.6 \pm 3.1 \mathrm{~kg}(\mathrm{P}<0.01)$ during the week of the study.

On the day after admission, after an overnight fast, adipose tissue samples were taken by subcutaneous needle biopsy from the anterior abdominal wall after $2 \%$ lignocaine local anæsthesia. After a further overnight fast, blood was taken to determine fasting plasma-triglyceride concentration. An 'Intralipid' (Vitrum) tolerance test was then performed with $10 \%$ intralipid at a dose of $0.1 \mathrm{~g} / \mathrm{kg} .{ }^{5}$ From this test a rate constant $\left(k_{2}\right)$ was calculated to express the rate of clearance of intralipid from the blood, and this has been shown to correlate with the fractional turnover rate of endogenous triglyceride. ${ }^{6}$ The patients remained in hospital and received clofibrate $1 \mathrm{~g}$ twice daily for 7 days, and the studies were repeated.

Lipoprotein lipase released by heparin in vitro was determined by incubating samples of adipose tissue $(100 \mathrm{mg})$ in Earle's bicarbonate buffer pH 7.4 containing $2.5 \%$ crystalline bovine serum albumin with and without heparin $(2 \mathrm{U} / \mathrm{ml})$ at $37^{\circ} \mathrm{C}$ for $1 \mathrm{~h}$. The media were then assayed for enzyme by means of a modification of the radiochemical method described by Krauss et al. ${ }^{7}$ The substrate consisted of a triglyceride emulsion stabilised by lysolecithin. $12.5 \mathrm{mg}$ of glycerol trioleate together with $6 \mu \mathrm{Ci}$ of glycerol tri[ $\left[1{ }^{14} \mathrm{C}\right.$-oleate, and 25 $\mu \mathrm{l}$ of $5 \%$ lysolecithin were ultrasonicated for $4 \mathrm{~min}$ at maximum power by means of an MSE $100 \mathrm{~W}$ ultrasonic disintegrator with titanium probe, in a solution of $6 \mathrm{ml}$ of $0.16 \mathrm{~mol} / \mathrm{l}$ "tris"/hydrochloric-acid buffer pH 8.1 containing $20 \mathrm{mg}$ of crystalline bovine serum albumin. $250 \mu$ l of this substrate emulsion was used in each assay with $100 \mu 1$ of normal human serun taken while fasting, to activate the enzyme. Incubations were at $37^{\circ} \mathrm{C}$ for $1 \mathrm{~h}$, and then $200 \mu \mathrm{l}$ was extracted in a Belfrage Vaughan partition system. ${ }^{8} 1 \mathrm{ml}$ of the upper phase was counted in a Packard liquid scintillation counter model 2420 .

Extractable lipase was determined by treating an homogenate of adipose tissue $(100 \mathrm{mg})$ with acetone/ether $(2 / 1 \mathrm{v} / \mathrm{v})$ The extract was then homogenised in a $0.05 \mathrm{~mol} / \mathrm{l}$ ammoniumchloride buffer $\mathrm{pH} 8 \cdot 6$, and the homogenate assayed for lipoprotein lipase as above. Adipose-cell size and triglyceride content were determined, ${ }^{9}$ enabling results of enzyme activity to be expressed as a nmol free fatty acid (F.F.A.) $/ 10^{6}$ cells $/ \mathrm{h}$. Results are expressed as means \pm S.E.M., and significance of differences calculated by Student's paired $t$ test.

\section{Results}

Mean fasting plasma triglyceride decreased from $6.85 \pm 1.1$ to $2.66 \pm 0.29 \mathrm{mmol} / \mathrm{A}(\mathrm{P}<0.01)$ and the in vivo measurement of triglyceride clearance $\left(k_{2}\right)$ increased in all patients (see accompanying table) on clofibrate therapy. This was associated with an almost twofold increase in the activity of adipose-tissue heparin-releasable and extractable lipoprotein lipase (table). The heparin-releasable lipase increased in all six 